\title{
Retracted article: Principal component, chemical, bacteriological, and isotopic analyses of Oued-Souf groundwaters
}

\author{
Hakim Saibi · Mohamed Mesbah • A. S. Moulla •
}

Sachio Ehara

Received: 25 January 2009/Accepted: 13 October 2009/Published online: 30 October 2009

(C) Springer-Verlag 2010

The article has been retracted due to copyright issues that cannot be resolved.

The article has been retracted due to copyright issues that cannot be resolved.

H. Saibi $(\bowtie) \cdot$ S. Ehara

Laboratory of Geothermics, Department of Earth Resources

Engineering, Faculty of Engineering, Kyushu University,

744 Motooka, Nishi-ku, Fukuoka 819-0395, Japan

e-mail: saibi-hakim@mine.kyushu-u.ac.jp

M. Mesbah

Faculty of Earth Science, University of Science and Technology

Houari Boumedienne, Algiers, Algeria

\section{A. S. Moulla}

Nuclear Research Center of Algiers, 2 Boulevard Strantel Fanol,

P.O. Box 399, 16000 Algiers, Algeria 